\title{
Uji Durabilitas Jembatan Kereta Api dengan Menggunakan Analisis Mikrotremor
}

\section{Durability Test of Railway Bridge by Using Microtremor Analysis}

\author{
Adib Maulana ${ }^{1}$, and Rini Kusumawardani ${ }^{2)}$ \\ ${ }^{1)}$ Department of Civil Engineering, Universitas Negeri Semarang, Sekaran, Gunung Pati, Semarang City Post \\ Code 50229, \\ e-mail: adibredcomet@gmail.com \\ ${ }^{2)}$ Department of Civil Engineering, Universitas Negeri Semarang, Sekaran, Gunung Pati, Semarang City Post \\ Code 50229, \\ e-mail: rini.kusumawardani@mail.unnes.ac.id
}

\begin{abstract}
ABSTRAK
Jematan adalah sarana yang menghubungkan jalan yang terpisah oleh sungai, lembah, laut, jalan atau rel kereta api. Berdasarkan fungsinya, jalan dibagi menjadi jembatan jalan dan jembatan rel kereta api. Penelitian ini membahas perilaku respons dinamik dari struktur jembatan. Dengan mencari nilai getaran, penelitian ini menggunakan sensor accelerometer dan alat seismic monitoring pada jembatan rangka batang. Sensor diletakkan pada setengah dan sepertiga bentang. Kemudian, hasil dari penelitian membandingkan respons jembatan ketika dilewati kereta api penumpang dengan kereta api barang. Ketika jembatan tidak dilewati beban, rentang frekuensi natural dan amplitudo jembatan sebesar $0.78 \mathrm{~Hz} ; 1.82 \mathrm{sampai}$ $3.73 \mathrm{~Hz} ; 1.89$. Ketika dilewati kereta, rentang frekuensi natural dan amplitudo menjadi $1.03 \mathrm{hz} ; 1.70$ sampai $5.77 \mathrm{~Hz} ; 4.14$. Perubahan ini diasumsikan karena adanya perbedaan kecepatan kereta api, beban kereta api dan perletakan sensor. Berdasarkan hasil penelitian, jembatan dapat menahan bahaya resonansi yang ditimbulkan oleh getaran tanah. Untuk pengukuran lebih lanjut, dibutuhkan pengukuran getaran jalan di dekat jembatan untuk mendapatkan analisis yang lebih lengkap.
\end{abstract}

Kata-kata kunci: Jembatan rel kereta, jembatan rangka, getaran, pengukuran in-situ, accelerometer

\section{ABSTRACT}

The bridge is a means of connecting roads which is disconnected by barriers of the river, valley, sea, road or railway. Classified by functionality, bridges can be divided into highway bridge and railroad bridge. This study discusses the dynamic response of bridges. By finding out the value of the vibrations, this study uses accelerometer and seismic monitoring on a truss bridge. The tools are placed on the beam at a half span and at a third span. The results were compared between passsanger train and carriage train. During free vibrations, the range of frequency natural and amplitude are between $0.78 \mathrm{~Hz} ; 1.82$ to $3.73 \mathrm{~Hz} ; 1.89$. When the train passes by, the range of frequency natural and amplitude are between $1.03 \mathrm{~Hz} ; 1.70$ to $5.77 \mathrm{~Hz} ; 4.14$. It is assumed that, because of changing speed of the train, train load and the sensors placement. Based on these results, it can be said that the brige has resistance towards the resonance danger of the ground. For the next measurement, it needs to measure the stress that occur to obtain more complete analysis.

Key words: Railway bridges, truss bridge, vibration, in situ measurements, accelerometer

\section{PENDAHULUAN}

Getaran bumi dihasilkan oleh banyak sumber independen yang mempengaruhi frekuensi dari keseluruhan gelombang natural. Frekuensi di bawah $1 \mathrm{~Hz}$ sebagian besar dihasilkan oleh gelombang laut dan peristiwa meteorologi dengan skala besar. Pada frekuensi di atas $1 \mathrm{~Hz}$, bidang gelombang di lingkungan perkotaan didominasi oleh sumber kegiatan manusia, terutama lalu lintas, sedangkan area yang jauh dari urbanisasi gelombang dihasilkan angin dalam jumlah yang dominan. Gelombang getaran yang dihasilkan pada wilayah urban menunjukan kebiasaan yang berhubungan dengan kegiatan manusia.

Pengukuran ambient noise dengan frekuensi di bawah $1 \mathrm{~Hz}$ dapat membantu dalam pemahaman kita tentang interaksi antara bumi, lautan dan atmosfer. Ambient noise dalam rentang frekuensi $1-10 \mathrm{~Hz}$ (umumnya dikenal sebagai microtremor) dapat memberikan solusi eksplorasi dengan biaya rendah dan noninvasif di daerah perkotaan yang mana informasi geoteknik sering sulit diperoleh. Sebagai hasil pengukuran mikrotremor telah digunakan dalam banyak penelitian untuk menentukan frekuensi resonansi, kecepatan rambat gelombang dan ketebalan sedimen. Data-data ini dapat digunakan untuk memprediksi amplifikasi lokal gerak tanah selama gempa bumi dan untuk persiapan peta mikrozonasi seismik. Informasi semacam itu sangat penting untuk penilaian bahaya seismik. Prediksi berdasarkan data microtremor telah diverifikasi menggunakan teknik esiemic lainnya. Misalnya, pola amplifikasi gerak tanah yang diamati selama gempa sebanding dengan pola amplifikasi yang dimodelkan dari data microtremor.

Respon dari jembatan rel kereta api ketika dilewati merupakan salah satu hal krusial untuk kenyamanan penumpang dan juga untuk menjaga struktur jembatan tersebut dalam kondisi yang baik. Dengan bertambahnya kecepatan kereta dan beban yang diangkut, amplitudo dari perilaku dinamis jembatan dan rel akan meningkat (Lorieux, 2008). Trek rel kereta yang rigid mempunyai perilaku non-elastis, maka dari itu ketika terjadi getaran, perpindahan partikel balas seringkali irreversible dan akumulasi dari perpindahan minor ini mengakibatkan settlement dan degradasi dari trek itu sendiri. Ketika trek kereta api mengalami penurunan kualitasnya, maka dapat dipastikan akan berpengaruh pada kenyamanan penumpang dan keamanannya.

Kompleksitas respon struktur terhadap beban kereta berdasarkan interaksi bagian dari system track-bridge; rel, sleepers, balas, gelagar dan pondasi. Tiap elemen dari jembatan memiliki perilaku sendiri dengan karakteristik yang berbeda. Akibat perbedaan non-linear dari tiap masing-masing elemen, sangat sulit untuk memprediksikan penyebaran tegangan dan getaran dari tiap elemen

Berbagai tipe model percobaan sudah dikembangkan tiap tahunnya, seperti berfokus pada satu elemen saja pada struktur. Dengan berkembangnya kemampuan komputerisasi, perhitungan mulai dikembangkan reaksi antar dua elemen atau lebih. Pada 
artikel kali ini, kami hanya akan berfokus dan menyajikan data dari penelitian microtremor pada Jembatan Kereta BH-9 Kaligawe. Tujuan dari eksperimen ini adalah meneliti dan menganalisa sinyal microtremor untuk menguji ketahanan Jembatan Kereta BH-9 Kaligawe, Semarang.

\section{DASAR TEORI}

\section{Horizontal to Vertical Spectral Ratio (HVSR)}

Merode HVSR merupakan metode yang digunakan sebagai indikator struktur bawah permukaan tanah yang memperlihatkan hubungan antara rasio spektrum fourier dari sinyal mikrotremor komponen horizontal terhadap komponen vertikalnya. Metode HVSR menggunakan tiga arah komponen gelombang yaitu dua komponen horizontal dan satu komponen vertikal. Hasil dari metode HVSR yaitu frekuensi natural dan amplifikasi (Wifayanti, 2013).

Data mikroseismik yang didapat dari hasil penelitian selanjutnya akan diolah menggunakan software Geopsy.

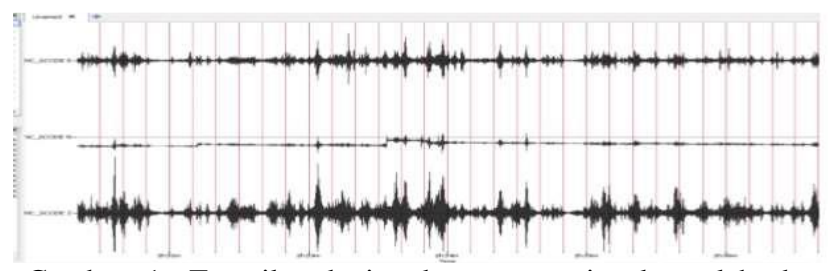

Gambar 1. Tampilan ketiga komponen sinyal setelah data diinput pada software Geopsy

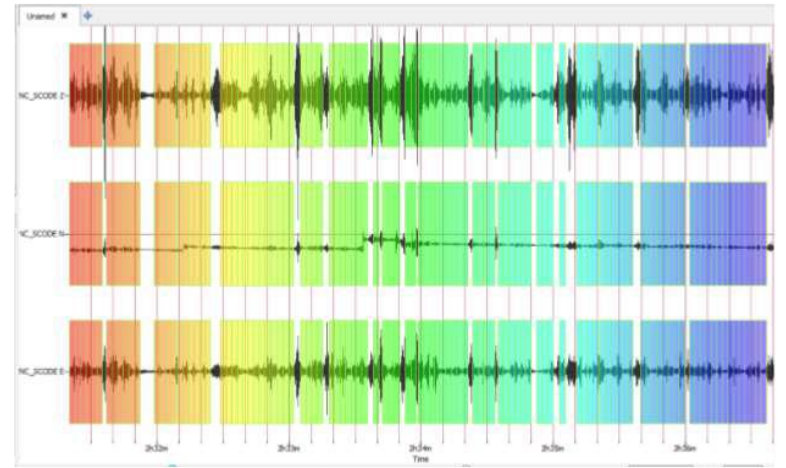

Gambar 2. Tampilan setelah dilakukan pemilihan sinyal tanpa noise pada software Geopsy

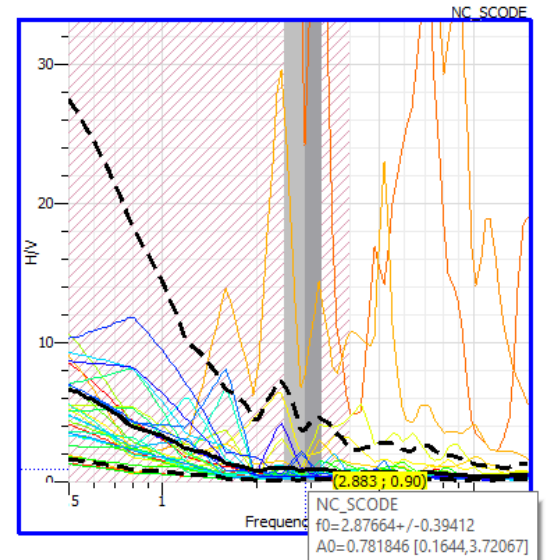

Gambar 3. Tampilan grafik H/V

Nilai dari hasil metode HVSR dapat dimanfaatkan untuk menentukan nilai percepatan getaran maksimum, amplitudo dan frekuensi natural.

\section{Frekuensi Natural (fo)}

Frekuensi alami struktur adalah frekuensi dari struktur yang secara alami cenderung untuk bergetar jika struktur ini terkena gaya/gangguan. Bentuk getaran dari sebuah struktur adalah bentuk lendutan pada frekuensi yang spesifik, hal ini dapat didapatkan dengan melakukan modal analysis tersebut (Wahyuni, 2012).

Nilai frekuensi alami ini dapat digunakan sebagai pedoman apakah suatu struktur akan mengalami resonansi atau tidak. Suatu struktur akan mengalamai resonansi apabila nilai frekuensi beban yang diterima struktur mendekati atau sama dengan frekuensi alaminya (Wahyuni, 2012). Biasanya, pada 3 atau 4 mode pertama yang dipertimbangkan berpotensi terjadi resonansi. Frekuensi alami pertama berkisar antara $3-4 \mathrm{~Hz}$ untuk getaran horizontal. Bila frekuensi alami pada jembatan dibawah $5 \mathrm{~Hz}$ maka struktur harus dicek pada kemampuan menerima getaran, seperti disebutkan pada British Standart (BSI, 2005).

\section{Jembatan}

Menurut Struyck dan Van Der Veen (1984), jembatan merupakan sebuah struktur yang dibangun melewati suatu rintangan yang berada lebih rendah. Rintangan-rintangan tersebut dapat berupa sungai, danau, saluran irigasi, rawa, jurang, lembah serta raya yang melintang tidak sebidang.

\section{Jembatan Rangka Warren (Warren Truss Bridge)}

Jembatan ini ditemukan Jems Warren dan Willoughby Monzari (Inggris), pada tahun 1848. Dapat dikenali dengan adanya banyak segitiga sama kaki atau segitiga sama sisi pada struktur atasnya, segitiga ini berbentuk seperti jaringan yang dihubungkan pada tiap joint pada bagian atas dan bawahnya. Segitiga ini dibagi lagi menjadi bagian yang lebih kecil dan lebih ringan.

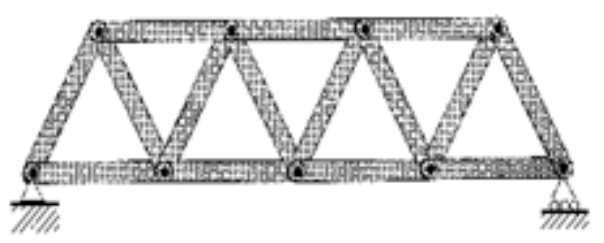

Gambar 4. Warren Truss

\section{Gaya Beban Dinamis Kereta Api}

Beban kereta api yang diterima rel merupakan beban dinamis yang menghasilkan gelombang permukaan (rayleigh wave). Getaran yang dihasilkan mempunyai arah getaran vertikal dan lateral yang akan diteruskan ke struktur jembatan melalui bantalan rel. gaya getaran yang terjadi dapat dihitung dengan persamaan

$$
F=m_{R^{*} \alpha}
$$

dengan,

$$
\begin{array}{ll}
\alpha & =\text { percepatan }\left(\mathrm{m} / \mathrm{s}^{2}\right) ; \\
\mathrm{F} & =\text { gaya akibat beban dinamis kereta }(\mathrm{kN}) ; \\
\mathrm{M}_{\mathrm{R}} & =\text { massa roda }(\mathrm{kg}) .
\end{array}
$$
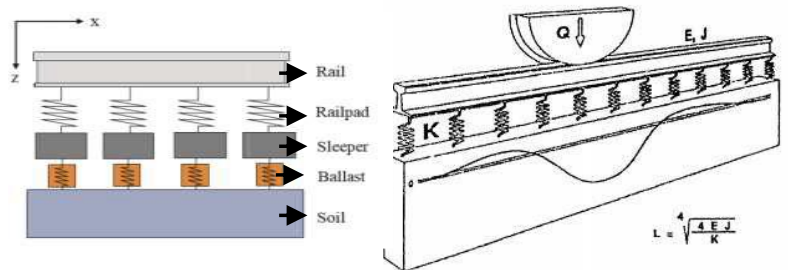

Gambar 5. Distribusi getaran kereta api

Beban kereta api diasumsikan sebagai beban merata yang terpusat pada roda-roda kereta. Seperti gambar di atas, beban 
akibat kereta didistribusikan melalui besi rel untuk diteruskan ke bantalan melalui railpad yang elastis sehingga mempertahankan bentuk rel pada keadaan semula. Beban getaran dari bantalan diteruskan ke balas yang berfungsi sebagai peredam getaran sehingga beban getaran yang mengenai tanah dasar tidak terlalu besar.

Ketika kereta melewati rel maka akan menghasilkan getaran yang diukur dalam bentuk percepatan dan frekuensi gelombang. Saat roda kereta melewati besi rel dan bantalan maka akan mengakibatkan frekuensi yang besarnya dipengaruhi kecepatan saat kereta melaju (Suhairy, 200). Menurut Suhairy (2000) untuk jarak bantalan as ke as sebesar $0.65 \mathrm{~m}$, kereta dengan kecepatan $25 \mathrm{~m} / \mathrm{s}(90 \mathrm{~km} / \mathrm{jam})$ akan memiliki frekuensi maksimal sebesar $38.5 \mathrm{~Hz}$

\section{Permodelan Respon Jembatan saat Dilewati Beban Bergerak}

Keseluruhan struktur jembatan dabat dimodelkan sebagai simply supported beam (Fryba, 2000). Tiap gelagar memiliki mode pergetaran yang berbeda. Rumus untuk mengetahui frekuensi dari getaran tersebut adalah sebagai berikut:

$$
f_{j}=\frac{j^{2} \pi}{2 L^{2}} \sqrt{\frac{E I}{\mu}}
$$

dengan,

$$
\begin{aligned}
f_{\mathrm{j}} & =\text { frekuensi dari mode ke-j; } \\
\mathrm{L} & =\text { panjang bentang jembatan; } \\
\mathrm{E} & =\text { modulus elastisitas; } \\
\mathrm{I} & =\text { momen inersia dari penampang gelagar; } \\
\mu & =\text { massa linear dari gelagar. }
\end{aligned}
$$

Selanjutnya, permodelan dasar untuk jembatan dengan asumsi gelagar sederhana dengan panjang $\mathrm{L}$ juga telah dilakukan oleh Fryba (Fryba, 2000). Dalam permodelan ini, kereta yang melewati jembatan dimodelkan sebagai gaya pusat yang bergerak. Setiap gandar direpresentasikan sebagai gaya yang bekerja pada gelagar dan bergerak dengan kecepatan konstan c dari kiri ke kanan. Hasilnya, gelagar akan menerima serangkaian gaya dalam bentuk $\mathrm{Fn}, \mathrm{n}=1,2 \ldots \mathrm{N}$ dimana $\mathrm{N}$ adalah jumlah gandar.

Gambar 6. Permodelan jembatan dan beban bergerak oleh Fryba (Fryba, 2000)

Perilaku gelagar dapat dirumuskan dengan rumus BernoulliEuler:

$$
E I \frac{\partial^{4} v(x, t)}{\partial x^{4}}+\mu \frac{\partial^{2} v(x, t)}{\partial t^{2}}+2 \mu \omega_{d} \frac{\partial v(x, t)}{\partial t}=\sum_{n=1}^{N} \varepsilon_{n}(t) \delta\left(x-x_{n}\right) F_{n}
$$

dimana,

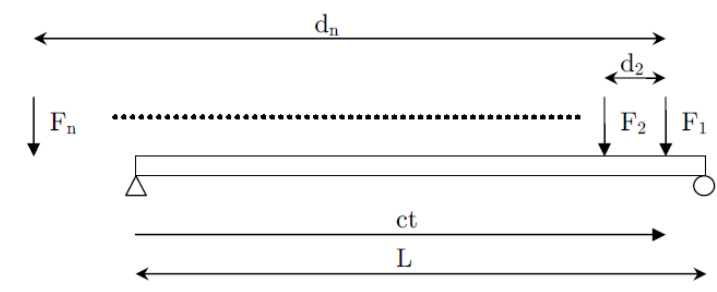

$\mathrm{v}(\mathrm{x}, \mathrm{t})=$ defleksi vertikal gelagar pada titik $\mathrm{x}$ dan waktu $\mathrm{t}$;

$\omega_{\mathrm{d}} \quad=$ damping parameter;

$\varepsilon_{\mathrm{n}} \quad=\mathrm{H}\left(\mathrm{t}-\mathrm{t}_{\mathrm{n}}\right)-\mathrm{H}\left(\mathrm{t}-\mathrm{T}_{\mathrm{n}}\right)$;

$$
\begin{array}{ll}
\text { dimana, } & \\
\mathrm{H} & =\text { Heaviside unit function; } \\
\delta & =\text { Dirac function/gaya terpusat; } \\
& \frac{d_{n}}{c} ; \text { adalah waktu ketika gandar ke-n }
\end{array}
$$
melewati jembatan; dan

$$
\mathrm{T}_{\mathrm{n}} \quad=\frac{L+d_{n}}{c} \text {; adalah waktu ketika gandar ke-nth telah }
$$
melewati jembatan.

$\mathrm{x}_{\mathrm{n}}=\mathrm{ct}-\mathrm{d}_{\mathrm{n}}$; adalah posisi gandar ke-n di jembatan

Dengan menggunakan perhitungan transformasi integral fourier dan integral Laplace-Carson, dapat digunakan untuk menghitung defleksi vertikal dan kemudian nilai lain seperti percepatan pada gelagar sebagai fungsi dari posisi dan waktu.

Rumus defleksi dan percepatan yang dideskripsikan oleh model Fryba (Fryba, 2000) adalah sebagai berikut:

$$
\begin{aligned}
& v(x, t)=\sum_{j=1}^{\infty} \sum_{n=1}^{N} v_{0} \frac{F_{n}}{F} j \omega \omega_{1}^{2}\left[f\left(t-t_{n}\right) h\left(t-t_{n}\right)-(-1)^{j} f\left(t-T_{n}\right) h\left(t-T_{n}\right)\right] \sin \left(\frac{j \pi x}{L}\right) \\
& a(x, t)=\sum_{j=1}^{\infty} \sum_{n=1}^{N} v_{0} \frac{F_{n}}{F} j \omega \omega_{1}^{2}\left[\ddot{f}\left(t-t_{n}\right) h\left(t-t_{n}\right)-(-1)^{j} \ddot{f}\left(t-T_{n}\right) h\left(t-T_{n}\right)\right] \sin \left(\frac{j \pi x}{L}\right)
\end{aligned}
$$

persamaan di atas melambangkan:

$\omega \mathrm{f} \quad=2 \pi f \mathrm{f}$ adalah frekuensi natural circular dari jembatan;

$\omega$

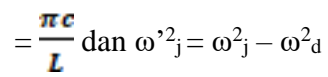

$v_{0}$ $=\frac{2 F}{\mu L \omega^{2}} ;$ adalah defleksi dari gelagar pada titik karena

gaya F;

$$
\begin{aligned}
& =\frac{1}{\omega_{p}^{p}}\left[\frac{\omega_{j}^{p}}{j \omega} \sin (j \omega t+\lambda)-\sin \left(\omega_{j}^{b} t+\varphi\right) e^{-\omega_{i} t}\right] \\
& \text { dengan, } \\
& D=\left(\omega j^{2}-j^{2} \omega^{2}\right)^{2}+4 j^{2} \omega^{2} \omega d^{2} \\
& \lambda=\arctan \left(\frac{-2 j \omega \omega_{d}}{\omega j^{2}-j^{2} \omega^{2}}\right) \\
& \varphi=\arctan \left(\frac{2 \omega_{d} \omega_{j}^{s}}{\omega d^{2}-\omega^{s} j^{2}+j^{2} \omega^{2}}\right)
\end{aligned}
$$

\section{METODE PENELITIAN}

\section{Data Jembatan}

Data umum jembatan yang menjadi objek dalam analisis adalah sebagai berikut:

Jembatan : Jembatan BH-9 Kaligawe, Semarang

Lokasi : Kaligawe-Banget Ayu KM 3+2/3, Semarang

Lebar : $: 5.13 \mathrm{~m}$

Panjang : $42 \mathrm{~m}$

Material : Baja

Tumpuan: Sendi-rol

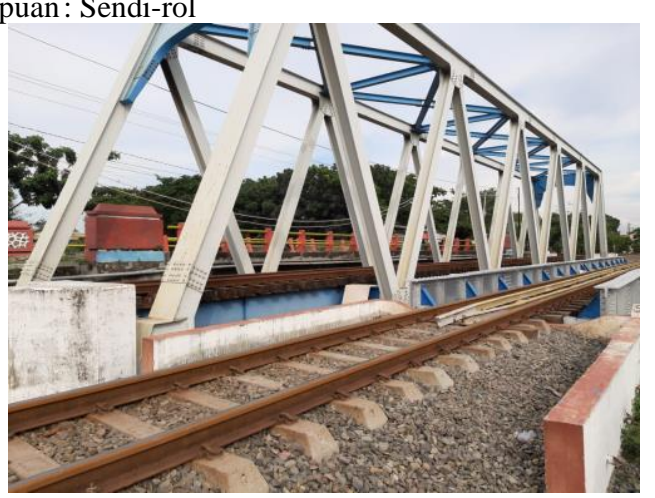

Gambar 6. Jembatan BH-9 Kaligawe 


\section{Data Getaran Akibat Kereta Api}

Data yang didapat di lokasi penelitian merupakan data percepatan getaran yang direkam menggunakan sensor accelerometer yang dipasang di lokasi penelitian. Sensor diletakkan pada gelagar jembatan dengan dua variasi pereltakan, yaitu di tengah bentang dan di sepertiga bentang. Berikut merupakan langkah-langkah pengambilan data di lapangan:

1. Menyiapkan semua alat dan perlengkapan untuk dibawa ke lokasi penelitian.

2. Meletakkan sensor di beberapa bagian bentang jembatan kereta api agar dapat menjangkau getaran yang di itimbulkan ketika kereta api melintasi jembatan tersebut. Sumbu X pada sensor accelerometer menghadap arah timur.

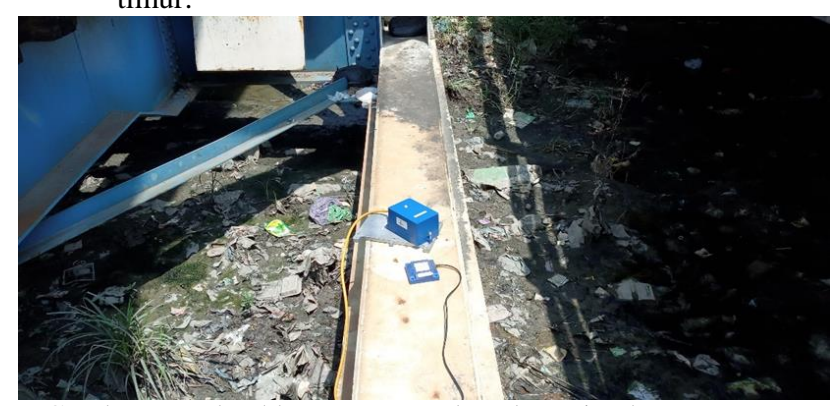

Gambar 7. Peletakkan sensor pada gelagar jembatan

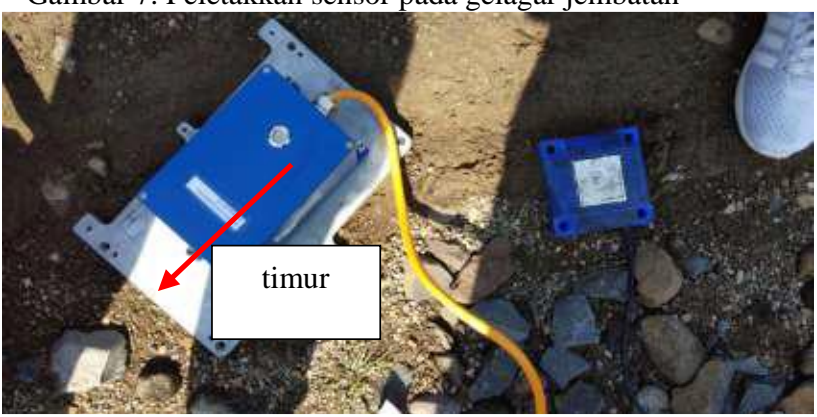

Gambar 8. Arah sumbu X menghadap timur

3. Memersiapkan alat recorder yang akan dihubungkan ke laptop dan sensor untuk merekam data mikrotremor. Kemudian hubungkan alat dengan kabel.

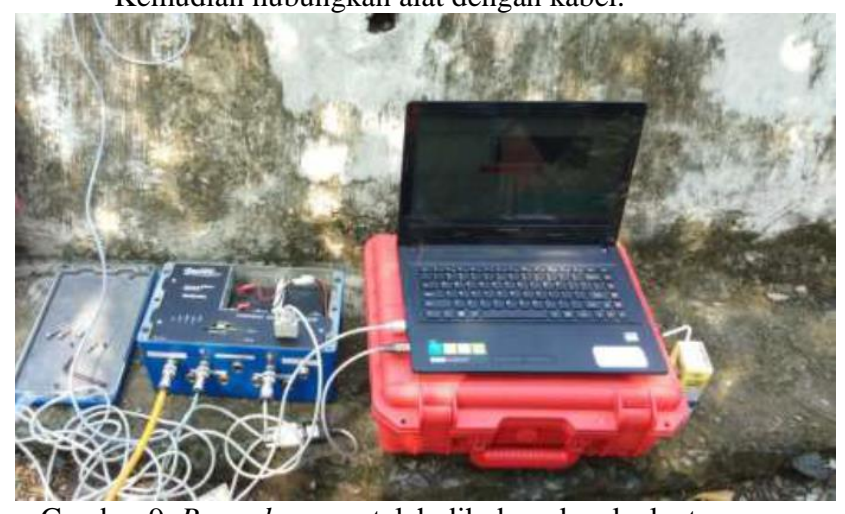

Gambar 9. Recorder yang telah dihubungkan ke laptop

4. Setelah semua alat terhubung, kemudian nyalakan recorder dan membuka software GeoDAS.

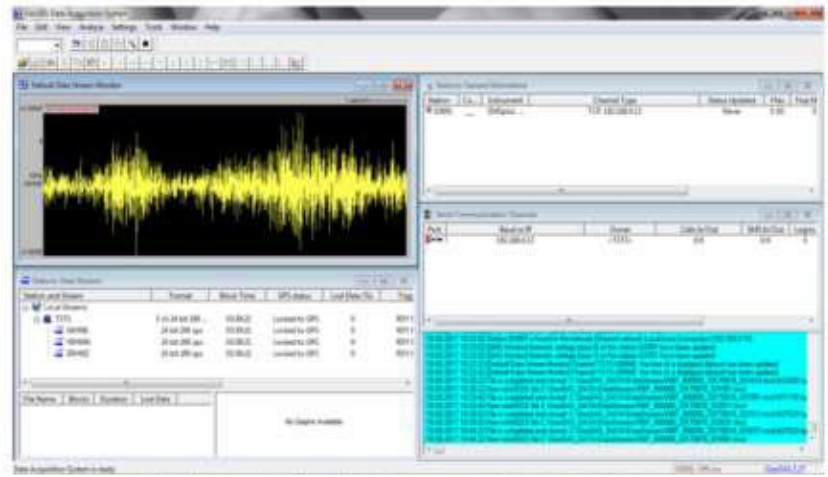

Gambar 10. Tampilan software GeoDAS

\section{Analisis Data Mikrotremor}

Setelah didapat data penelitian, data kemudian di olah menggunakan aplikasi GeoDAS dan Geopsy. Saat penelitian di lapangan alat sensor accelerometer dihubungkan dengan laptop yang sudah terinstall software GeoDAS. Data mikrotemor yang sudah terekam di GeoDAS akan otomatis tersimpan.

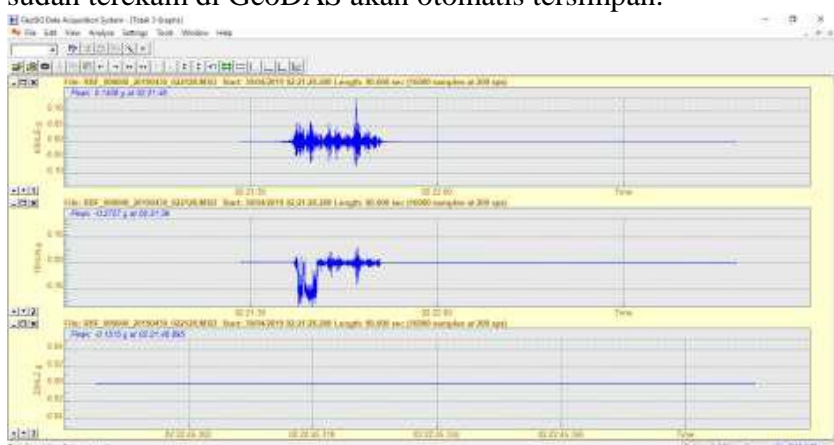

Gambar 11. Tampilan data percepatan getaran pada software GeoDAS

Data mikrotemor pada software GeoDAS kemudian diubah ke format ASCII agar bisa diolah menggunakan software Geopsy. Setelah didapat data percepatan dari sensor accelerometer, data kemudian diolah menggunakan software Geopsy untuk mendapatkan data frekuensi (f) dan amplitudo (A).

\section{HASIL DAN PEMBAHASAN}

Setelah melakukan pengumpulan data dan analisis menggunakan software Geopsy, maka didapat frekuensi natural, percepatan getaran maksimum dan amplitude. Selanjutnya, hasil data yang telah diolah ditampilkan dalam bentuk table dan grafik yang selanjutnya dapat ditarik kesimpulan.

Nilai frekuensi natural yang dapat diterima menurut SNI (2008) mengenai ketahanan jembatan terhadap beban gempa yaitu dengan jumlah total $2.63 \mathrm{~Hz}$ dan maksimum lendutan sebesar $0.0036 \mathrm{~m}$. Nilai ini yang menjadi acuan dalam standarisasi jembatan di seluruh Indonesia.

\section{Beban Kereta Api}

Beban kereta api dihitung berdasarkan data beban gandar, beban lokomotif dan beban gerbong. Beban gandar diambil maksimal 18 ton, beban lokomotif sebesar 90 ton dan beban gerbong untuk kereta barang maksimum 54 ton dan beban gerbong untuk kereta penumpang beserta penumpangnya maksimal sebesar 40 ton.

\section{Kecepatan Kereta Api}

Kecepatan kereta api yang ditinjau yakni kecepatan kereta saat melintasi sensor accelerometer dan alat seismic monitoring. Pada penelitian tanggal 7 Maret 2020 kereta yang melintas meliputi kereta penumpang Maharani dan Argo Anggrek serta kereta barang. Kemudian pada tanggal 9 Maret 2020 kereta yang 
melintas adalah kereta penumpang yaitu Maharani-2, Kedung Sepur dan Argo Anggrek-2.

Tabel 1. Data kecepatan kereta api

\begin{tabular}{clc}
\hline Nomor & Jenis Kereta & $\begin{array}{c}\text { Kecepatan, v } \\
(\mathrm{km} / \mathrm{jam})\end{array}$ \\
\hline 1 & Kereta Maharani & 72.42 \\
2 & Kereta Argo Anggrek & 75.64 \\
3 & Kereta barang & 51.50 \\
4 & Kereta Maharani-2 & 74.03 \\
5 & Kereta Kedung Sepur & 56.33 \\
6 & Kereta Argo Anggrek-2 & 78.86 \\
\hline
\end{tabular}

\section{Getaran Kereta Api}

Getaran kereta api merupakan getaran yang diakibatkan oleh kereta api saat melintasi rel. getaran kereta api akan didistribusikan ke rel kemudian ke bantalan dan diteruskan ke ballast. Ballast berfungsi sebagai peredam getaran sehingga getaran yang terjadi pada tanah dasar tidak terlalu besar.

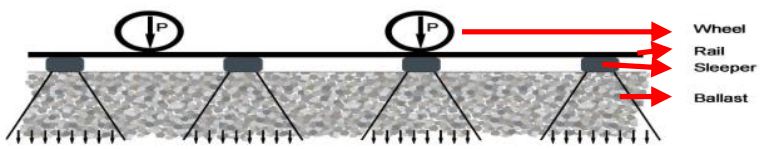

Gambar 12. Distribusi beban dari roda ke balas atau deck jembatan

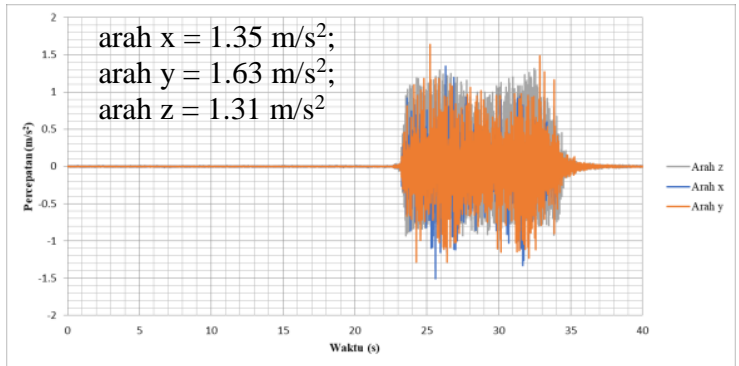

Gambar 13. Grafik percepatan getaran KA Argo Anggrek

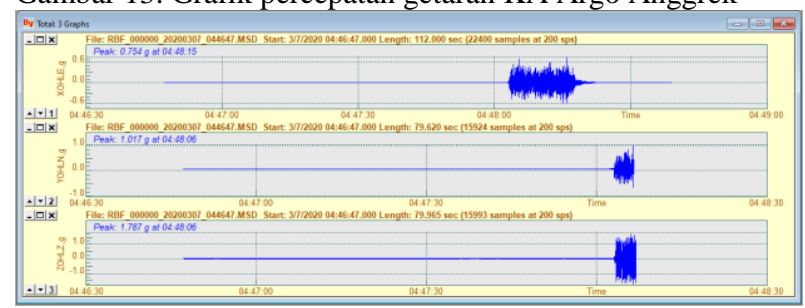

Gambar 14. Percepatan getaran KA Argo Anggrek menggunakan GeoDAS

Tabel 2. Data kecepatan kereta api

\begin{tabular}{|c|c|c|c|c|c|}
\hline \multirow{2}{*}{ Nomor } & \multirow{2}{*}{ Jenis Kereta } & \multirow{2}{*}{$\begin{array}{c}\text { Kecepatan, v } \\
(\mathrm{km} / \mathrm{jam})\end{array}$} & \multicolumn{3}{|c|}{ Percepatan max, a (g) } \\
\hline & & & $\operatorname{arah} x$ & $\operatorname{arah} \mathrm{y}$ & $\operatorname{arah} \mathrm{z}$ \\
\hline 1 & Kereta Maharani & 72.42 & 1.23 & 1.42 & 1.31 \\
\hline 2 & Kereta Argo Anggrek & 75.64 & 1.35 & 1.63 & 1.31 \\
\hline 3 & Kereta barang & 51.50 & 1.37 & 1.49 & 1.31 \\
\hline 4 & Kereta Maharani-2 & 74.03 & 0.50 & 0.64 & 1.07 \\
\hline 5 & Kereta Kedung Sepur & 56.33 & 0.36 & 0.45 & 1.05 \\
\hline 6 & Kereta Argo Anggrek-2 & 78.86 & 1.05 & 0.63 & 1.19 \\
\hline
\end{tabular}

\section{Frekuensi dan Amplitudo Getaran}

Dari data penelitian yang didapat menggunakan alat accelerometer yang terhubung dengan recorder seismic monitoring, data tersebut diolah menggunakan software Geopsy untuk menentukan nilai frekuensi natural, amplifikasi dan frekuensi saat struktur jembatan dilewati kereta. Berdasarkan hasil pengolahan data menggunakan Geopsy yaitu data diolah menggunakan metode HVSR.

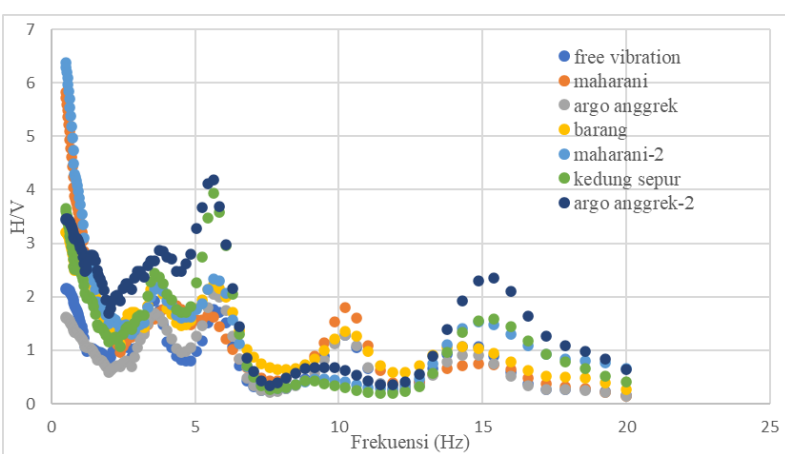

Gambar 15. Grafik hubungan frekuensi dan H/V berdasarkan jenis kereta

Dari pengolahan data menggunakan software Geopsy, ketika struktur dibiarkan tanpa ada beban/kereta yang melintas didapatkan nilai frekuensi natural sebesar $0.78 \mathrm{~Hz}$ dan amplitudo sebesar 1.88. Nilai frekuensi dan amplitudo paling besar yaitu kereta Argo anggrek dengan nilai $5.67 \mathrm{~Hz}$ dan amplitudo 2.03 . Letak sensor berada di sepertiga bentang jembatan. Sementara untuk perletakan sensor di tengah bentang, nilai frekuensi dan amplitudo paling besar yaitu kereta Maharani dengan nilai 5.77 Hz dan amplitudo 2.30.

\section{Nilai Frekuensi Natural Jembatan BH-9 Kaligawe, Jawa Tengah}

Dari pengolahan data menggunakan software Geopsy, ketika struktur dibiarkan tanpa ada beban/kereta yang melintas didapatkan nilai frekuensi natural sebesar $0.78 \mathrm{~Hz}$ dan amplitudo sebesar 1.88. Nilai frekuensi dan amplitudo paling besar yaitu kereta Argo anggrek dengan nilai $5.67 \mathrm{~Hz}$ dan amplitudo 2.03. Letak sensor berada di sepertiga bentang jembatan. Sementara untuk perletakan sensor di tengah bentang, nilai frekuensi dan amplitudo paling besar yaitu kereta Maharani dengan nilai 5.77 $\mathrm{Hz}$ dan amplitudo 2.30. Berdasarkan nilai frekuensi yang telah didapat, frekuensi natural jembatan sebesar $0.78 \mathrm{~Hz}$ berada di bawah nilai $2.63 \mathrm{~Hz}$ menurut Standar Nasional Indonesia (2008) tentang ketahanan struktur jembatan terhadap gempa. Kemudian dari semua jenis kereta yang melintasi struktur jembatan tersebut nilai frekuensi naturalnya berada di atas frekuensi natural jembatan. Ketika frekuensi kereta di atas nilai frekuensi jembatan maka kemungkinan struktur untuk mengalami resonansi menjadi kecil.

Frekuensi natural Jembatan BH-9 didapat saat kereta api melintas dengan asumsi beban yang maksimum. Gambar 17 menunjukkan grafik HVSR dari jembatan Ketika dilewati kereta KA Agro Anggrek (Kereta penumpang) melintas. Terdapat dua jenis data HVSR dari hasil pengamatan, yaitu ketika dilewati kereta dan ketika tidak ada kereta yang melintas

Dari gambar 17, didapat nilai frekuensi natural dari jembatan sebesar $5.5 \mathrm{~Hz}$. Selanjutnya dari hasil analisis menggunakan Geopsy, Gambar 19, ketika jembatan tidak dilewati kereta nilai frekuensi natural jembatan sebesar $0.78 \mathrm{~Hz}$

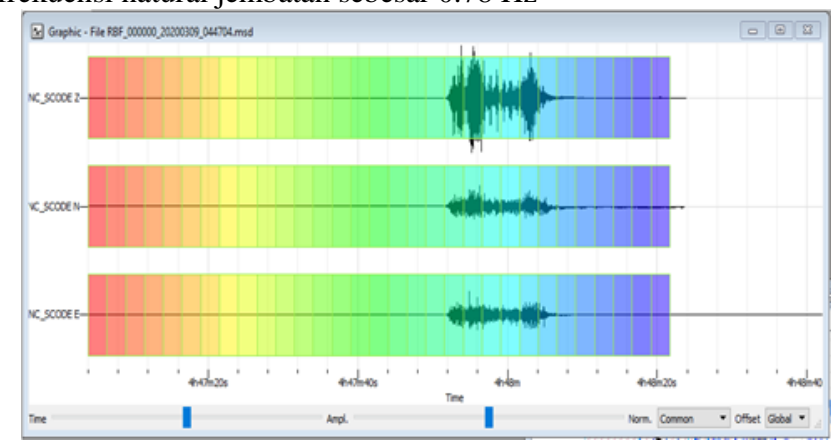

Gambar 16. Windowing ambient signals 


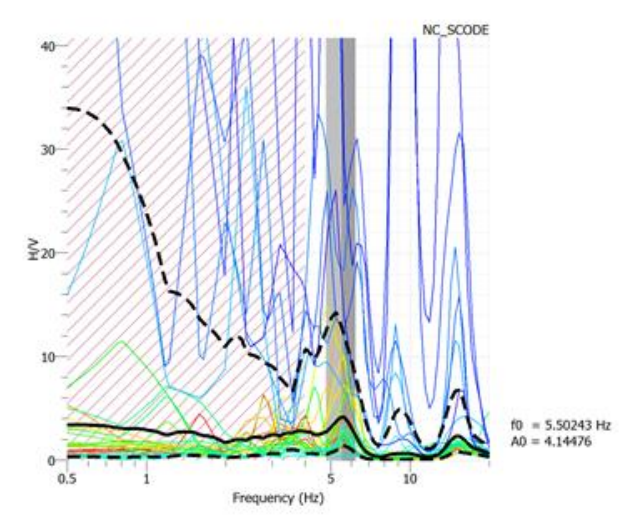

Gambar 17. Kurva HVSR ketika dilewati KA Agro Anggrek

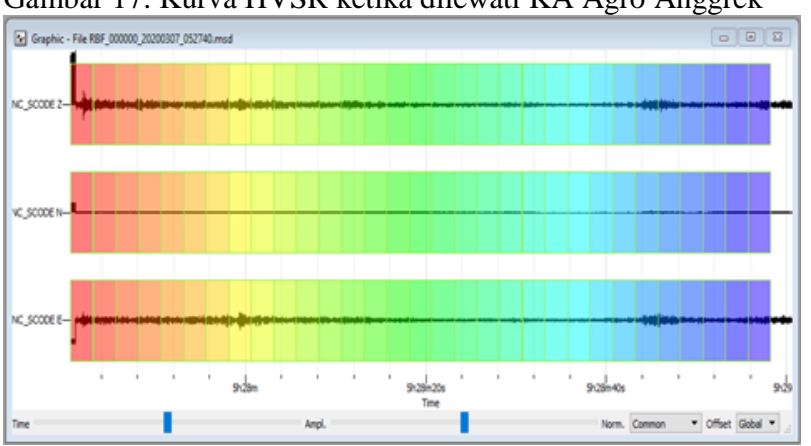

Gambar 18. Windowing ambient signals

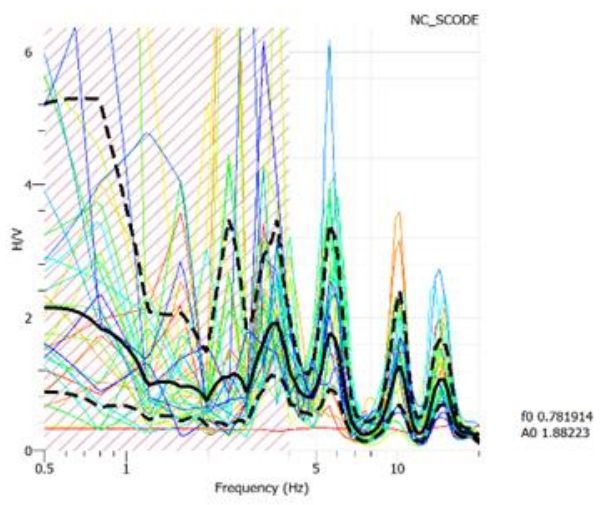

Gambar 19. Kurva HVSR ketika tidak dilewati kereta

\section{SIMPULAN}

Berdasarkan pembahasan dan pengolahan data hasil penelitian maka disimpulkan beberapa hal sebagai berikut:

1. Besarnya getaran dari kereta api yang diwujudkan dalam bentuk percepatan getaran didapat menggunakan alat berbasis accelerometer yaitu accelerometer AC-73 yang tersambung dengan alat seismic monitoring. Berdasarkan data penelitian yang didapat dari alat accelerometer, percepatan getaran akibat beban kereta api sebesar 0.36 $\mathrm{m} / \mathrm{s} 2-1.37 \mathrm{~m} / \mathrm{s} 2$ untuk arah $\mathrm{x}, 0.45 \mathrm{~m} / \mathrm{s} 2-1.63 \mathrm{~m} / \mathrm{s} 2$ untuk arah y dan $1.05 \mathrm{~m} / \mathrm{s} 2-1.31 \mathrm{~m} / \mathrm{s} 2$ untuk arah $\mathrm{z}$.

2. Dari pengolahan data menggunakan software Geopsy didapat nilai frekuensi natural struktur sebesar $0.78 \mathrm{~Hz}$ dan amplitudo 1.88. Sementara nilai frekuensi natural saat kereta melintas sebesar $1.03 \mathrm{~Hz}-5.77 \mathrm{~Hz}$ dan amplitudo sebesar $1.70-4.14$. Nilai frekuensi terbesar terjadi ketika kereta Argo Anggrek melintas dengan kecepatan 78.86 $\mathrm{km} / \mathrm{jam}$ yang menghasilkan frekuensi natural $5.50 \mathrm{~Hz}$ dan amplitudo 4.14 .

3. Jembatan dapat dikategorikan aman jika tidak terjadi resonansi ketika menerima beban dinamis dari kereta. Nilai frekuensi natural yang mendekati akan mengakibatkan kemungkinan resonansi yang lebih tinggi. Nilai frekuensi natural jembatan ketika tidak dilewati beban adalah sebesar $0.78 \mathrm{~Hz}$. Sementara ketika dilewati beban kereta, nilai frekuensi jembatan berubah menjadi sebesar $1.03 \mathrm{~Hz}-5.77$ Hz. Dari analisis getaran yang telah dilakukan, nilai frekuensi natural ketika dilewati kereta berada di atas nilai frekuensi struktur jembatan ketika tidak ada beban. Oleh karena itu, jembatan BH-9 Kaligawe dapat dikategorikan memiliki kemampuan dalam menerima getaran.

\section{PERSEMBAHAN TERIMA KASIH}

Penulis sangat berterima kasih atas bantuan dan saran dari Dr. Rini Kusumwaradani.

\section{DAFTAR NOTASI}

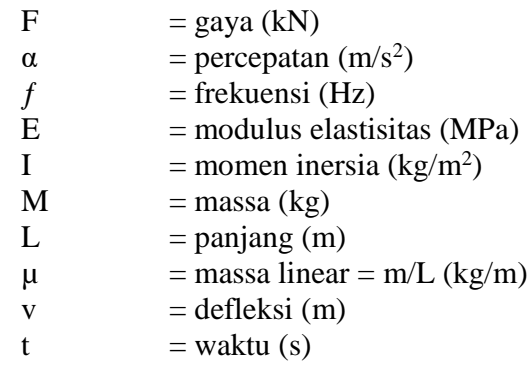

\section{DAFTAR PUSTAKA}

Bonnefoy-Claudet, Cotton F., and Bard P.Y., Earth-Science Reviews 79, 205-227, (2006).

D.E. McNamara, and Buland R.P., Bulletin of the Seismological Society of America 94, 1517-1527, (2004)

F. Cara, Di Giulio G., and Rovelli A., Geophysical Research Letters 30, 1972. doi:10.1029/2003GL017807, (2003).

Fryba L. 2000. A Rough Assessment of Railway Bridges for High Speed Trains. Engineering Structures (23): 548 - 556.

Lorieux, Louis. 2008. Analysisi of train-induced vibrations on a single-span composite bridge. Royal Institute of Technology (KTH). Swedia.

M. Bhattarai, Individual Studies by Participants at the International Institute of Seismology and Earthquake Engineering 41, 73-86, (2005).

M. Ohori, Nobata A, and Wakamatsu K., Bulletin of the Seismological Society of America 92, 2323-2332, (2002).

S. Kedar, and Webb F.H., Science 307, 682-683, (2005).

S.C. Webb, Nature 445, 754-756, (2007).

Struyk, H.J. \& Van der Veen, K.H.C.W. (1984). JembatanKonstruksi. Terjemahan Soemargono. Jakarta: PT.Pradnya Paramita.

Suhairy S. 2000. Prediction of Ground Vibration from Railways. SP Sweedish National Testing and Research Institute: Sweedish.

Wahyuni, Endah. 2012. Studi Kelakuan Dinamis Struktur Jembatan Penyeberangan Orang (JPO) akibat Beban Individual Manusa Bergerak. Jurnal Teoritis dan Terapan Bidang Rekayasa Sipil 19(3): 181-194.

Wifayanti, Eka J. Sunkgono. 2013. Estimasi Indeks Kerentanan Tanah menggunakan Metode HVSR (Horizontal to Vertical Spectral Ratio). Jurnal. 2337-3520. 